\title{
Determination of Ametryn in River Water, River Sediment and Bivalve Mussels by Liquid Chromatography-Tandem Mass Spectrometry
}

\author{
Analu E. Jacomini, ${ }^{a}$ Plinio B. de Camargo, ${ }^{b}$ Wagner E. P. Avelar ${ }^{a}$ and Pierina S. Bonato ${ }^{* c}$ \\ ${ }^{a}$ Departamento de Biologia, Faculdade de Filosofia, Ciências e Letras de Ribeirão Preto, \\ Universidade de São Paulo, Av. Bandeirantes, 3900, 14040-901 Ribeirão Preto-SP, Brazil
}

\author{
${ }^{b}$ Centro de Energia Nuclear Aplicada, Universidade de São Paulo, Av. Centenário, 303, 13416-000 Piracicaba-SP, Brazil \\ 'Departamento de Física e Química, Faculdade de Ciências Farmacêuticas de Ribeirão Preto, \\ Universidade de São Paulo, Av. Café, s/n, 14040-903 Ribeirão Preto-SP, Brazil
}

\begin{abstract}
Foram descritos métodos analíticos empregando cromatografia líquida acoplada a espectrometria de massas (LC-MS-MS) para a determinação de ametrina em água superficial, sedimento de rio e no molusco bivalve Corbicula fluminea. A técnica de extração líquido-líquido foi utilizada para a preparação das amostras. As análises das amostras foram feitas em coluna RP-18 de fase reversa com detecção no modo electrospray positivo e Multi Reaction Monitoring (MRM). O limite de quantificação de ametrina foi $20 \mathrm{ng} \mathrm{L}^{-1}, 0,1 \mathrm{ng} \mathrm{g}^{-1} \mathrm{e} 0,5 \mathrm{ng} \mathrm{g}^{-1}$ para amostras de água, sedimento e bivalves, respectivamente. Na etapa de validação dos métodos foram avaliadas também a linearidade, a precisão, a exatidão e a recuperação. Os resultados obtidos na validação do método estão de acordo com os limites internacionais e com a literatura, sugerindo que o método desenvolvido é adequado para a quantificação de ametrina em amostras de água superficial, sedimento de rio e nos bivalves Corbicula fluminea. Estes métodos foram aplicados na análise de amostras coletadas no Rio Mogi-Guaçu e Rio Pardo, São Paulo, Brasil. O nível mais elevado de ametrina foi $1,44 \mathrm{ng} \mathrm{g}^{-1}$, encontrado nas amostras de bivalves do Rio Mogi-Guaçu.
\end{abstract}

Analytical methods employing liquid chromatography-mass spectrometry (LC-MS-MS) for ametryn determination in river water, river sediment and in freshwater bivalve mussel Corbicula fluminea are described. Liquid-liquid extraction was used for sample preparation. The analyses of ametryn in samples were performed on a reversed-phase RP-18 column with MS detection in positive electrospray and multi reaction monitoring modes. The quantitation limit of ametryn was $20 \mathrm{ng} \mathrm{L}^{-1}, 0.1 \mathrm{ng} \mathrm{g}^{-1}$ and $0.5 \mathrm{ng} \mathrm{g}^{-1}$, for water, sediment and bivalve samples, respectively. Linearity, precision, accuracy and recovery were also reported. The results obtained for method validation are within the international limits and in accordance with literature, suggesting that the developed methods are suitable for the quantitation of ametryn in river water, river sediment and in bivalve Corbicula fluminea. These methods were applied for the analysis of samples from Mogi-Guaçu River and Pardo River, São Paulo State. Results indicated that the highest level of ametryn was $1.44 \mathrm{ng} \mathrm{g}^{-1}$ in bivalve samples from Mogi-Guaçu River.

Keywords: ametryn, liquid chromatography, mass spectrometry, method validation, environmental analysis

\section{Introduction}

Ametryn (2-ethylamino-4-isopropylamino-6-methylthio-s-triazine) is a triazine herbicide used for pre and post emergence control of weeds in cultures of corn, sugar cane and others. The EPA (Environmental Protection Agency) classifies it as toxicity class III, which is slightly

*e-mail: psbonato@fcfrp.usp.br toxic. Ametryn is moderately toxic to fish, highly toxic to crustaceans and moderately to highly toxic to mollusks. ${ }^{1}$ This herbicide was selected for the study because it is the major triazine herbicide applied in sugar cane cultures in the northeastern region of São Paulo state, Brazil. That region is the largest alcohol producing center in Brazil, with approximately 4 millions hectares with sugar cane culture. ${ }^{2}$ The extensive use of ametryn in sugar cane culture, reported by Gomes ${ }^{3}$ and Armas and Monteiro, ${ }^{4}$ its properties such as 
aerobic soil half life of 53.2 days, ${ }^{5}$ adsorption coefficient ${ }^{5}$ (Koc) of 3.45 and leaching potential ${ }^{4}$ of 6.9 suggest that this herbicide could be present in the environment as a potential contaminant of soil and surface and ground water. Contamination of surface water in São Paulo state (Brazil) by ametryn, ranging from 0.17 to $0.23 \mu \mathrm{g} \mathrm{L}^{-1}$, has been reported by Cerdeira et al..$^{6}$ Laabs et al. ${ }^{7}$ reported water and sediment contamination by ametryn in Pantanal region, Dores et al. ${ }^{8}$ reported superficial and groundwater contamination by atrazine and simazine in Primavera do Leste region (Mato Grosso state) and Zuin et al. ${ }^{9}$ reported sugar-cane juice contamination by ametryn in São Carlos city, all in Brazil.

The analysis of pesticides in macroinvertebrate tissue can be used to assess the bioaccumulation of pollutants in aquatic food chains and to provide background information on contaminant concentrations in streams, rivers and lakes/ reservoirs. ${ }^{10}$ Freshwater bivalve mussels have been used by our group as biomonitor for the presence of organochlorine pesticides $^{11-13}$ and atrazine ${ }^{14}$ in São Paulo state Brazil.

In order to evaluate the real contamination by pesticides in the freshwater ecosystem, it is important the development of methods that could be used for the determination of pesticides not only in water, but also in sediment samples and in aquatic organisms, such as bivalve mussel species. However, the analysis of pesticides in sediment and in biological samples may be a little bit more complicated, when compared to water samples since these matrices contain components that interfere in the analyte determination. In addition, the confirmation of pesticide in these samples requires more selective techniques such as mass spectrometry (MS) detection combined with gas or liquid chromatography (GC-MS, LC-MS or LC-MS-MS), which improve the selectivity and sensitivity of the analysis, and allow the simplification of sample preparation. ${ }^{15}$

Nowadays, the technological advances for analytical determination of low levels of compounds in complex samples are in the direction of using LC-MS-MS. Using atmospheric pressure ionization interfaces, particularly electrospray ionization (ESI), and triple-quadrupole-type instruments, it is possible to combine powerful features such as efficient separation, identification and quantification of analytes present in complex matrices and at low level concentrations, which are ideal for pesticide analysis. Further, no additional derivatization step is necessary.

Some methods using LC-MS or LC-MS-MS are described in the literature for the analysis of triazine herbicides in water, ${ }^{16-21}$ soil and sediment ${ }^{17,22}$ and biological environmental samples, including foods. ${ }^{16,23-26}$ However none of them allow the complete evaluation of the aquatic environment by analyzing simultaneously water, sediment and aquatic organisms. So the purpose of this study was to develop and validate practical and simple analytical methods for ametryn determination in river water, river sediment and in the bivalve Corbicula fluminea, a biomonitor organism, by LC-MS-MS analysis, and to apply these methods to environmental samples, suspected to contamination, collected in rivers near agricultural zones.

\section{Experimental}

\section{Reagents}

The stock solution of ametryn (99.1\% Supelco, Inc., USA) was prepared in HPLC-grade methanol (OmniSolv, Canada) at the concentration of $1 \mathrm{mg} \mathrm{mL}^{-1}$. The working solutions were prepared by appropriate dilutions of the stock solutions in the concentration range of 0.02 to $2 \mu \mathrm{g} \mathrm{m}^{-1}$. Water was purified with a Milli-Q-Plus system (Millipore, USA). The dichloromethane (Merck, Germany) and acetone (Mallinckrodt, EUA) utilized in the extraction procedures were HPLC-grade. All other reagents were P.A. grade obtained from Merck (Germany). The diazepam solution, used as surrogate, was prepared in methanol at the concentration of $2 \mu \mathrm{g} \mathrm{mL}{ }^{-1}$. The diazepam was chosen as surrogate due to its availability in the laboratory, its quantitative extraction and for not being found in the aquatic ecosystem. This data was confirmed through previous analyses by LC-MS-MS of the environmental samples, which did not show residues for this drug. The ammonium acetate buffer used in the mobile phase was filtered using a membrane of $0.45 \mu \mathrm{m}$ pore from Millipore (Brazil).

\section{Environmental samples}

The water and sediment samples used in the method validation were collected in August 2003 in Sapucaí River, São Joaquim da Barra City, Northeastern of São Paulo State, Brazil (20³1'012" S, 4750'279” W). Water samples were collected in polietilene flasks. The sediments (around $3 \mathrm{~kg}$ ) were collected in the river at a depth of 50 to $100 \mathrm{~cm}$ by probing the substrates with the hands. The samples were dried at $60^{\circ} \mathrm{C}$ until constant weight, homogenized and then stored in environment temperature $\left(25^{\circ} \mathrm{C}\right)$ before analysis. The pedological parameters are presented in Table 1 . The freshwater bivalve mussels utilized in the method validation were Corbicula fluminea, and were chosen because they were located in the substrates of the several rivers of São Paulo State, Brazil. Bivalves Corbicula fluminea was obtained in August 2003 in Sapucaí River, São Joaquim da Barra City, Northeastern of São Paulo State, Brazil 
(20³1'012”' S, 47050'279' W). The animals were collected in the river, at a depth of 50 to $100 \mathrm{~cm}$, by probing the substrates with the hands. The mean length of the bivalves was $1.98 \pm 0.61 \mathrm{~cm}(\mathrm{n}=40)$. The bivalves were transported to the laboratory, where they were frozen and the valves were removed. The soft parts of 40 animals were withdrawn and were triturated with a mechanical shaking (Marconi, model MA039) in a glass tube rending around $20 \mathrm{~g}$ of mass (wet weight). This composite sample was stored at $-20{ }^{\circ} \mathrm{C}$ until the analysis. There were no detectable levels of ametryn in the water and river sediment or in the bivalve mass used in the method validation.

To verify the ametryn contamination in the aquatic ecosystem, samples of river water, sediment and bivalve specimens Corbicula fluminea were collected in MogiGuaçu River, Pradópolis City (2121'918” S, 4808'774" W) in August 2004, and in Pardo River, Jardinópolis City (2103'866" S, 47050'600" W) in May 2004. Both rivers are localized in the northeastern region of São Paulo State, Brazil, where predominate intensive sugar cane agriculture. The pedological parameters of the river sediment samples are described in Table 1. Water samples collected in triplicates in Mogi-Guaçu and Pardo River, were frozen in polietilene flasks until analysis. The physical parameters of the river water samples are described in Table 2. The amount of bivalves collected in the Pardo and Mogi-Guaçu River were 32 and 41 specimens, respectively.

\section{Preparation of water samples}

Water samples from Mogi-Guaçu and Pardo Rivers were filtered in Millipore membrane (HV Durapore,
$0.45 \mu \mathrm{m}$ pore, $47 \mathrm{~mm}$ diameter) before extraction to remove suspended particles. Then, the samples were extracted in separation funnels with $12 \mathrm{~mL}$ of dichloromethane after alkalinization with $25 \mu \mathrm{L}$ of $\mathrm{NaOH} 4 \mathrm{~mol} \mathrm{~L}^{-1}$ and addition of $25 \mu \mathrm{L}$ of the surrogate solution (diazepam). These separation funnels were then maintained for $30 \mathrm{~min}$ in a horizontal shaker. After that, the organic phases of each separation funnel were collected, centrifuged for five $\min (1800 \mathrm{~g})$ and then $6 \mathrm{~mL}$ of these organic phases were recovered. These volumes were evaporated to dryness in an air flow, the residues were dissolved in $100 \mu \mathrm{L}$ mobile phase and $50 \mu \mathrm{L}$ were analyzed.

Calibration curves were prepared by spiking $100 \mathrm{~mL}$ of control water with $25 \mu \mathrm{L}$ of ametryn solutions at concentrations of $0.08,0.1,0.2,0.3$ and $0.4 \mu \mathrm{g} \mathrm{mL}^{-1}$, resulting ametryn concentrations in the samples of 0.02 , $0.025,0.05,0.075$ and $0.1 \mu \mathrm{g} \mathrm{L}^{-1}$. Although the use of calibration curves submitted to extraction is not a widespread practice for methods used in the analysis of environmental samples, we decide to use this procedure to have a better control of experimental errors during sample preparation.

\section{Preparation of sediment samples}

Spiked sediment samples were prepared by adding $25 \mu \mathrm{L}$ of an appropriate ametryn solution and $5 \mathrm{~mL}$ of acetone to $5 \mathrm{~g}$ of dry sediment samples. For the adsorption of the herbicide, these sediment samples were homogenized for $15 \mathrm{~min}$ in a mechanical shaker and next, they were allowed to stand open over-night to evaporate the solvent. For the extraction procedure, five grams of the spiked sediment

Table 1. Characteristics of river sediment samples

\begin{tabular}{|c|c|c|c|c|c|}
\hline \multirow{2}{*}{ Sediment } & \multicolumn{5}{|c|}{ Pedological parameter } \\
\hline & Granule and thick sand / $(\%)^{\mathrm{a}}$ & Medium and thin sand / $(\%)^{\mathrm{b}}$ & Silt and Clay / $(\%)^{\mathrm{c}}$ & Organic matter / $(\%)$ & $\mathrm{pH}^{\mathrm{d}}$ \\
\hline Sapucaí River & 0 & 34.14 & 65.86 & 0.89 & $6.74 \pm 0.01$ \\
\hline Pardo River & 4.13 & 41.53 & 53.98 & 9.18 & $6.41 \pm 0.02$ \\
\hline Mogi-Guaçu River & 84.63 & 13.87 & 1.50 & 1.36 & $7.21 \pm 0.05$ \\
\hline
\end{tabular}

${ }^{\mathrm{a}}$ From $2.00 \mathrm{~mm}$ to $1.00 \mathrm{~mm}$. ${ }^{\mathrm{b}}$ From $500 \mu \mathrm{m}$ to $125 \mu \mathrm{m} .{ }^{\mathrm{c}}<125 \mu \mathrm{m}$. ${ }^{\mathrm{d}}$ Analysis in triplicate (mean \pm standard deviation).

Table 2. Characteristics of river water samples

\begin{tabular}{lccccc}
\hline \multirow{2}{*}{ Water } & \multicolumn{4}{c}{ Physico-chemical parameters $^{\mathrm{a}}$} \\
& $\mathrm{T} /{ }^{\circ} \mathrm{C}$ & Dissolved oxygen $/(\%)$ & $\mathrm{pH}$ & ${\text { Conductivity } /\left(\mu \mathrm{S} \mathrm{cm}{ }^{-1}\right)}$ Turbid / (ntu) \\
\hline Sapucaí River & $20.5 \pm 0.17$ & $78.5 \pm 0.50$ & $5.82 \pm 0.83$ & $49.6 \pm 0.06$ & $8.9 \pm 0.02$ \\
Pardo River & $21.0 \pm 0.20$ & $77.0 \pm 1.00$ & $8.34 \pm 0.36$ & $52.6 \pm 0.06$ & $22.6 \pm 0.25$ \\
Mogi-Guaçu River & $19.5 \pm 0.25$ & $79.0 \pm 1.00$ & $8.67 \pm 0.49$ & $80.0 \pm 0.06$ & $10.9 \pm 0.06$ \\
\hline
\end{tabular}

${ }^{\mathrm{a}}$ Analysis in triplicate (mean \pm standard deviation). 
samples were mixed with $20 \mathrm{~mL}$ of acetone and $25 \mu \mathrm{L}$ of diazepam solution (surrogate); next, they were sonicated for $15 \mathrm{~min}$ and shaken for $10 \mathrm{~min}$ in a horizontal shaker. Approximately $15 \mathrm{~mL}$ of acetone was recovered after centrifugation for $10 \mathrm{~min}(1800 \mathrm{~g})$. After solvent evaporation, the residues were extracted with $2 \mathrm{~mL}$ of water, $5 \mathrm{~mL}$ of dichloromethane and $20 \mu \mathrm{L}$ of $\mathrm{NaOH} 1 \mathrm{~mol} \mathrm{~L}^{-1}$ for $30 \mathrm{~min}$ in a mechanical shaker. After centrifugation for $10 \mathrm{~min}$ $(1800 \mathrm{~g})$, the organic phases were collected, evaporated to dryness in an air flow and the residues were dissolved in $100 \mu \mathrm{L}$ mobile phase and $20 \mu \mathrm{L}$ were analyzed.

Calibration curves were prepared by spiking $5 \mathrm{~g}$ of control sediment sample with $25 \mu \mathrm{L}$ of ametryn solutions at concentrations of $0.02,0.04,0.1,0.3$ and $0.5 \mu \mathrm{g} \mathrm{mL}-1$, resulting ametryn concentrations in the samples of $0.1,0.2$, $0.5,1.5$ and $2.5 \mathrm{ng} \mathrm{g}^{-1}$.

Dry sediment samples from Mogi-Guaçu and Pardo Rivers were extracted according to the extraction procedure described above without the adsorption step.

\section{Preparation of bivalve samples}

A sample of $1 \mathrm{~g}$ of the bivalve mass (wet weight) was transferred to an extraction tube, followed by $10 \mathrm{~mL}$ water, $200 \mu \mathrm{L} \mathrm{HCl} 1 \mathrm{~mol} \mathrm{~L}^{-1}$ and $25 \mu \mathrm{L}$ of the surrogate solution. The tube was capped and sonicated for $10 \mathrm{~min}$, submitted to mechanical shaking for $10 \mathrm{~min}$ and centrifuged for $10 \mathrm{~min}$ at $1800 \mathrm{~g}$. The aqueous phase $(10 \mathrm{~mL})$ was transferred to a separation funnel and then $300 \mu \mathrm{L} \mathrm{NaOH} 1 \mathrm{~mol} \mathrm{~L}^{-1}$, $0.5 \mathrm{~g} \mathrm{NaCl}$ and $10 \mathrm{~mL}$ dichloromethane were added. The funnel was submitted to mechanical shaking for $30 \mathrm{~min}$. Then, the organic phase was transferred to a clean tube, centrifuged for $15 \mathrm{~min}$ at $1800 \mathrm{~g}$ and the recovered solvent was evaporated to dryness. The residue was dissolved in $100 \mu \mathrm{L}$ of mobile phase, centrifuged for $5 \mathrm{~min}$ to $1800 \mathrm{~g}$ to remove suspended solids and $20 \mu \mathrm{L}$ were analyzed.

Calibration curves were prepared by spiking $1 \mathrm{~g}$ of control bivalve sample with $25 \mu \mathrm{L}$ of ametryn solutions at concentrations of $0.04,0.1,0.3,0.5$ and $1 \mu \mathrm{g} \mathrm{mL}^{-1}$, resulting ametryn concentrations in the samples of $1,2.5,7.5,12.5$ and $25 \mathrm{ng} \mathrm{g}^{-1}$.

Air flow was employed for solvent evaporation in all extraction methods after the authors verify that ametryn and the surrogate was not degraded. The quantitation of ametryn in water, sediment and bivalve samples was made by plotting ametryn concentration $v s$. peak area ratio in a linear regression line establishing a fit weighting of $1 \mathrm{x}^{-1}$.

\section{Instrumentation and chromatographic conditions}

The water samples were firstly analyzed for ametryn in a HPLC system with UV detection and the results were confirmed by LC-MS-MS. The HPLC-UV analyses were performed in a Shimadzu liquid chromatography (Kyoto, Japan), consisting of a pump model LC-10AS, a UV detector model SPD-10A, a Rheodyne 7125 injector with $50 \mu \mathrm{L}$ loop and an integrator system model CR6-A. UV detection was performed at $230 \mathrm{~nm}$.

The LC-MS-MS analyses of water, sediment and bivalve samples were performed on a Quattro LC system (Micromass, Manchester, UK), with triple quadrupole in the Multiple Reaction Monitoring (MRM) mode and electrospray ionization in the positive mode. Ametryn and diazepam (surrogate) were firstly detected in the positive ion mode as their protonated molecular ion $(\mathrm{M}+\mathrm{H})^{+}$, which were previously chosen to be isolated and fragmented in the MS-MS mode. MRM was performed using the following precursor-fragment ions: $m / z, 228>186$ (ametryn) and $285>154$ (diazepam). The source block and desolvation temperatures were 100 and $250^{\circ} \mathrm{C}$, respectively. Nitrogen was used as both drying and nebulizing gas, and argon was used as collision gas. For water and sediment samples, the collision energy and the cone voltage were $20 \mathrm{eV}$ and $25 \mathrm{~V}$, respectively, for both ametryn and diazepam. For the bivalve samples, the collision energy and the cone voltage was $25 \mathrm{eV}$ and $30 \mathrm{~V}$, respectively, for ametryn and collision energy and the cone voltage was $30 \mathrm{eV}$ and $40 \mathrm{~V}$, respectively, for diazepam. The LC system (Shimadzu, Japan) consisted of two pumps model LC-10AD, a system controller model SCL-10A and a Rheodyne 7125i injector with a $20 \mu \mathrm{L}$ loop. The LC effluent was split by a valco valve and a flow rate of approximately $0.1 \mathrm{~mL} \mathrm{~min}^{-1}$ was introduced into the stainless steel capillary probe. The equipment was controlled by MassLynx NT V3.4 software for data acquisition and treatment.

The LC separation was performed in a reversed phase column Lichrospher 100 RP18 $(4 \times 125$ mm I.D., $5 \mu \mathrm{m}$, Merck, Germany) protected by a guard column Lichrospher 100 RP18 $(4 \times 4$ mm I.D., $5 \mu \mathrm{m}$, Merck, Germany). The mobile phase was methanol: ammonium acetate $0.01 \mathrm{moL} \mathrm{L}^{-1} \mathrm{pH} 6.6$ at a flow-rate of $1 \mathrm{~mL} \mathrm{~min}^{-1}$ (55:45, v/v for HPLC-UV analysis and 70:30, v/v for LCMS-MS analysis).

\section{Results and Discussion}

\section{Method for water analysis}

The liquid-liquid extraction of ametryn from water sample was performed in basic media with organic solvent in order to avoid ametryn protonation and to increase its recovery in the organic phase. The mobile phase used 
was methanol: ammonium acetate $0.01 \mathrm{~mol} \mathrm{~L}^{-1} \mathrm{pH} 6.6$ $(55: 45, \mathrm{v} / \mathrm{v})$. Figure 1 shows typical chromatograms of control water and water spiked with ametryn and diazepam (surrogate). The analysis time was less than $15 \mathrm{~min}$.

In the method validation, samples of control water spiked with known amounts of ametryn were used to analyze parameters such as: linearity, recovery, precision,
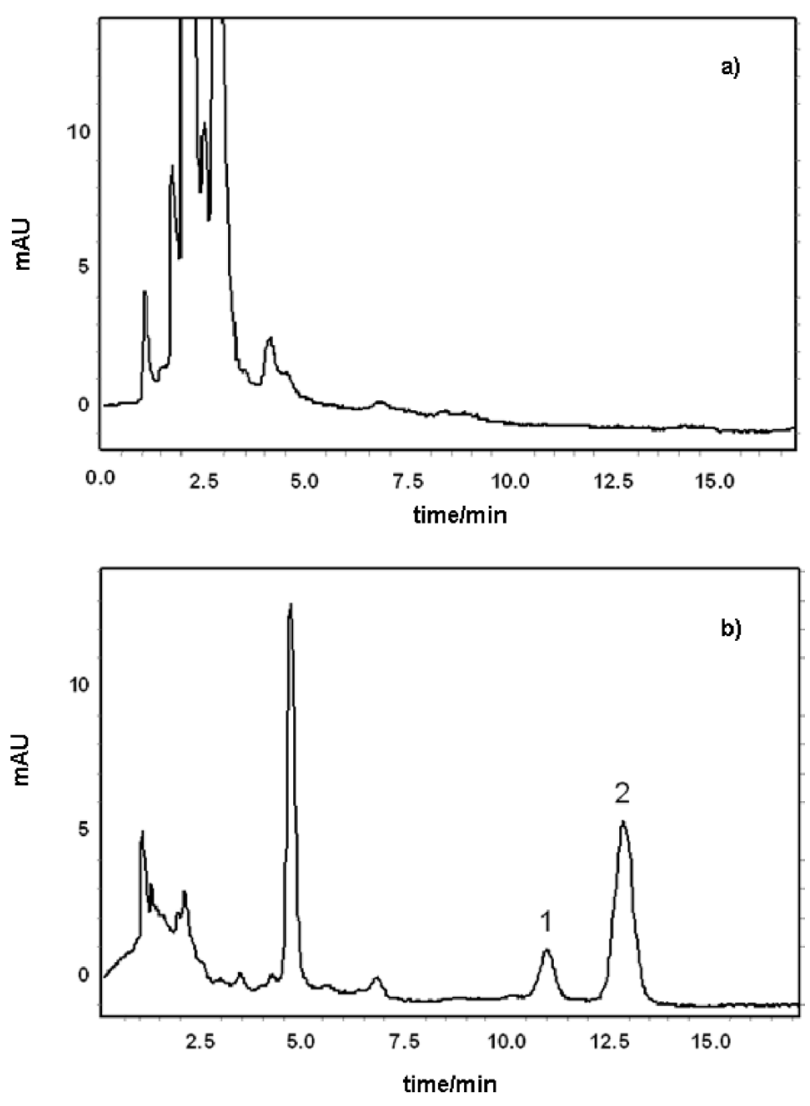

Figure 1. HPLC-UV chromatograms of control water (a) and water spiked with ametryn and the surrogate (b). Mobile phase, methanol:ammonium

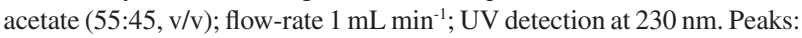
$1=\operatorname{ametryn}\left(75 \mathrm{ng} \mathrm{L}^{-1}\right) ; 2=\operatorname{surrogate}\left(500 \mathrm{ng} \mathrm{L}^{-1}\right)$. accuracy and limit of quantitation. Tables 3 and 4 summarize the data obtained in the method validation for water samples. The mean recovery was $51.2 \%(\mathrm{RSD}<7 \%)$, for 5 levels of concentration, ranging from 20 to $100 \mathrm{ng} \mathrm{L}^{-1}$, analyzed in duplicates for each concentration (Table 3). The linearity of the method extended up to $200 \mathrm{ng} \mathrm{L}^{-1}$, with $r=0.999$ (Table 4). The precision and accuracy was assessed by analysis of replicates of two spiked levels. The results showed RSD values lower than $15 \%$ and error values lower than $12 \%$ for all samples analyzed (Table 4$)$. The quantitation limit of the method was $20 \mathrm{ng} \mathrm{L}^{-1}$, evaluated in quintuplicate $(\mathrm{RSD}=3.1 \%$ and accuracy $=-0.6 \%$ ), a value five times below the international limit for residues of individual pesticides in water $\left(0.1 \mu \mathrm{g} \mathrm{L}^{-1}\right) .^{27}$ All values of RSD and accuracy obtained for the parameters analyzed in the validation method were considered acceptable according to literature. ${ }^{28,29}$ The limit of detection calculated at $\mathrm{S} / \mathrm{N}=3$ was $10 \mathrm{ng} \mathrm{L}^{-1}$, for ametryn analysis by HPLCUV and $0.9 \mathrm{ng} \mathrm{L}^{-1}$, for ametryn analysis by LC-MS-MS. This comparison proved the high sensibility of the MS detection. In addition, comparing this method with others LC-MS methods which have been recently described in literature for triazine analysis in water, ${ }^{16-21}$ we observe that this method presents the lowest quantitation and detection limits, besides it presents an easy manipulation.

\section{Method for river sediment analysis}

Sediment sample preparation was performed in two steps: ametryn extraction with acetone and clean-up in basic media with organic solvent and water. The chromatographic conditions were established using a reversed-phase RP-18 column and methanol: ammonium acetate $0.01 \mathrm{~mol} \mathrm{~L}^{-1}$ pH $6.6(70: 30, v / v)$ as the mobile phase. The ionization suppression effects between the ametryn and diazepam were verified through comparative analysis of ametryn

Table 3. Method recovery ${ }^{a}$ for ametryn analysis in water, sediment and bivalve

\begin{tabular}{|c|c|c|c|c|c|}
\hline Ametryn concentration & $\begin{array}{l}\text { Water / (ng L })^{-1}{ }^{b} \\
\text { Mean (RSD) }\end{array}$ & $\begin{array}{c}\text { Ametryn } \\
\text { concentration }\end{array}$ & $\begin{array}{l}\text { Sediment } /\left(\mathrm{ng} \mathrm{g}^{-1}\right)^{c} \\
\text { Mean }(\mathrm{RSD})\end{array}$ & $\begin{array}{c}\text { Ametryn } \\
\text { concentration }\end{array}$ & $\begin{array}{l}\text { Bivalve / }\left(\mathrm{ng} \mathrm{g}^{-1}\right)^{\mathrm{c}} \\
\text { Mean (RSD) }\end{array}$ \\
\hline 20 & $50.9(0.2)$ & 0.1 & $77.9(2.6)$ & 1.0 & $47.2(1.8)$ \\
\hline 25 & $50.0(6.2)$ & 0.2 & $68.6(4.1)$ & 2.5 & $68.6(5.0)$ \\
\hline 50 & $46.8(1.8)$ & 0.5 & $83.8(2.9)$ & 5.0 & $66.6(2.5)$ \\
\hline 75 & $51.6(2.9)$ & 1.5 & $69.7(2.2)$ & 7.5 & $63.7(2.6)$ \\
\hline 100 & $56.6(5.0)$ & 2.5 & $63.6(4.1)$ & 12.5 & $59.4(4.8)$ \\
\hline Mean recovery / (\%) & 51.2 & Mean recovery / $(\%)$ & 72.8 & Mean recovery / (\%) & 61.1 \\
\hline RSD / (\%) & 6.9 & RSD / (\%) & 11.0 & RSD / (\%) & 13.9 \\
\hline
\end{tabular}

${ }^{\text {a }}$ concentrations of ametryn in the extracted samples were determined using a calibration curve not submitted to extraction; ${ }^{\mathrm{b}}$ duplicate for each concentration; "triplicate for each concentration; RSD = relative standard deviation. 
Table 4. Results of precision, accuracy, quantitation limit and linearity of the methods for ametryn analysis in water, sediment and bivalve

\begin{tabular}{|c|c|c|c|c|c|c|c|c|}
\hline \multirow[b]{2}{*}{ Spiked } & \multicolumn{2}{|c|}{ Water / $\left(\mathrm{ng} \mathrm{L}^{-1}\right)$} & \multicolumn{3}{|c|}{ Sediment / $\left(\mathrm{ng} \mathrm{g}^{-1}\right)$} & \multicolumn{3}{|c|}{ Bivalve / $\left(\mathrm{ng} \mathrm{g}^{-1}\right)$} \\
\hline & 25.00 & 100.00 & 0.25 & 1.00 & 2.00 & 2.00 & 10.00 & 20.00 \\
\hline \multicolumn{9}{|l|}{ Within-day precision } \\
\hline Mean $^{\mathrm{a}}$ & 22.00 & 95.00 & 0.24 & 1.01 & 2.01 & 2.11 & 9.89 & 20.79 \\
\hline$n^{b}$ & 5 & 5 & 5 & 5 & 5 & 4 & 4 & 4 \\
\hline RSD & 5.6 & 6.0 & 4.6 & 11.9 & 3.3 & 5.9 & 10.1 & 10.0 \\
\hline Accuracy / (\%) & -11.6 & -5.2 & -1.6 & 1.2 & 0.4 & 5.6 & -1.0 & 3.9 \\
\hline \multicolumn{9}{|c|}{ Between-day precision } \\
\hline Mean $^{\mathrm{a}}$ & 23.62 & 99.20 & 0.24 & 1.01 & 2.01 & 1.91 & 9.88 & 18.38 \\
\hline $\mathrm{n}^{\mathrm{c}}$ & 5 & 5 & 3 & 3 & 3 & 3 & 3 & 3 \\
\hline RSD & 14.8 & 8.6 & 5.9 & 12.9 & 9.5 & 9.5 & 8.7 & 12.9 \\
\hline Accuracy / (\%) & -5.5 & -0.8 & -1.3 & 0.1 & 0.3 & -4.4 & -1.2 & -8.1 \\
\hline Quantitation limit & \multicolumn{2}{|c|}{20.00} & \multicolumn{3}{|c|}{0.10} & \multicolumn{3}{|c|}{0.50} \\
\hline Mean $^{\mathrm{a}}$ & \multicolumn{2}{|c|}{19.92} & \multicolumn{3}{|c|}{0.104} & \multicolumn{3}{|c|}{0.51} \\
\hline$n^{\mathrm{b}}$ & \multicolumn{2}{|c|}{5} & \multicolumn{3}{|c|}{5} & \multicolumn{3}{|c|}{5} \\
\hline RSD & \multicolumn{2}{|c|}{3.1} & \multicolumn{3}{|c|}{7.0} & \multicolumn{3}{|c|}{13.0} \\
\hline Accuracy / (\%) & \multicolumn{2}{|c|}{-0.6} & \multicolumn{3}{|c|}{0.4} & \multicolumn{3}{|c|}{1.6} \\
\hline Regression equation & \multicolumn{2}{|c|}{$y=6.472 x-0.016 ; r=0.999$} & \multicolumn{3}{|c|}{$y=1.868 x+0.037 ; r=0.999$} & \multicolumn{3}{|c|}{$y=0.069 x+0.036 ; r=0.997$} \\
\hline Linear range & \multicolumn{2}{|c|}{$20-200$} & \multicolumn{3}{|c|}{$0.10-5.00$} & \multicolumn{3}{|c|}{$0.50-25.00$} \\
\hline
\end{tabular}

${ }^{\mathrm{a}}$ mean obtained for ametryn concentration; ${ }^{\mathrm{b}}$ number of replicates for each concentration; ${ }^{\mathrm{c}}$ number of days; RSD $=$ relative standard deviation.

and diazepam solutions isolated and mixed. To verify the ionization suppression effects from the matrix compounds (river sediment) a blank sediment sample was extracted and the extract was spiked with ametryn and diazepam just before the injection into the LC-MS-MS system. The areas obtained were compared with those obtained for ametryn and diazepam without the matrix. No ionization suppression was observed, thereby, the quantification of ametryn and diazepam (surrogate) was possible in the same retention time, and without ionization suppression effects from the matrix compounds. The analysis time was less than $5 \mathrm{~min}$, which is an additional advantage of the LC-MS-MS method.

Figure 2 shows the product ion mass spectra of ametryn and diazepam. Figure 3 shows the MRM chromatograms of ametryn and diazepam of a spiked sediment sample.

The parameters evaluated in the validation were linearity, recovery, accuracy, precision and limit of quantitation. For these evaluations, river sediment samples obtained from Sapucai River (São Joaquim da Barra City) were spiked with appropriate ametryn solutions. The results obtained are shown in Tables 3 and 4 . The recovery for the spiked sediment samples were $72.8 \%$ with precision lower than $12 \%$ for 5 levels of concentration, ranging from 0.1 to $2.5 \mathrm{ng} \mathrm{g}^{-1}$, analyzed in triplicates for each concentration (Table 3). The linearity of the method extended up to $5 \mathrm{ng} \mathrm{g}^{-1}$, with
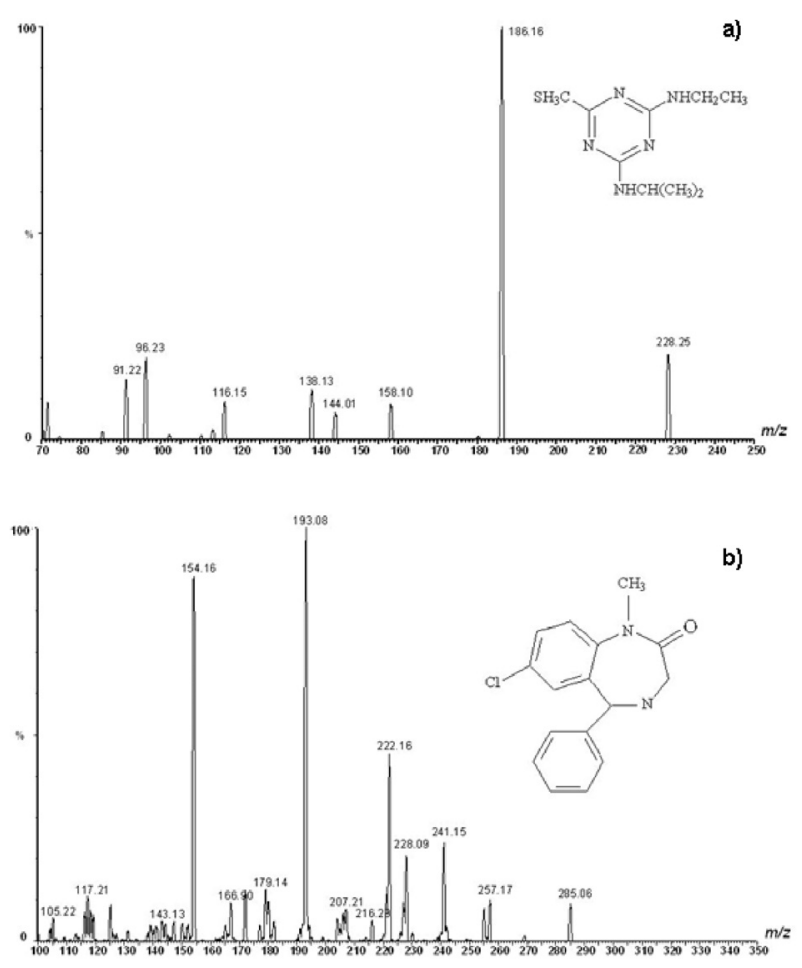

Figure 2. Product ion mass spectra of ametryn (a) and surrogate (b).

$\mathrm{r}=0.999$ (Table 4). The precision and accuracy were assessed in replicates of three levels of concentration. The 

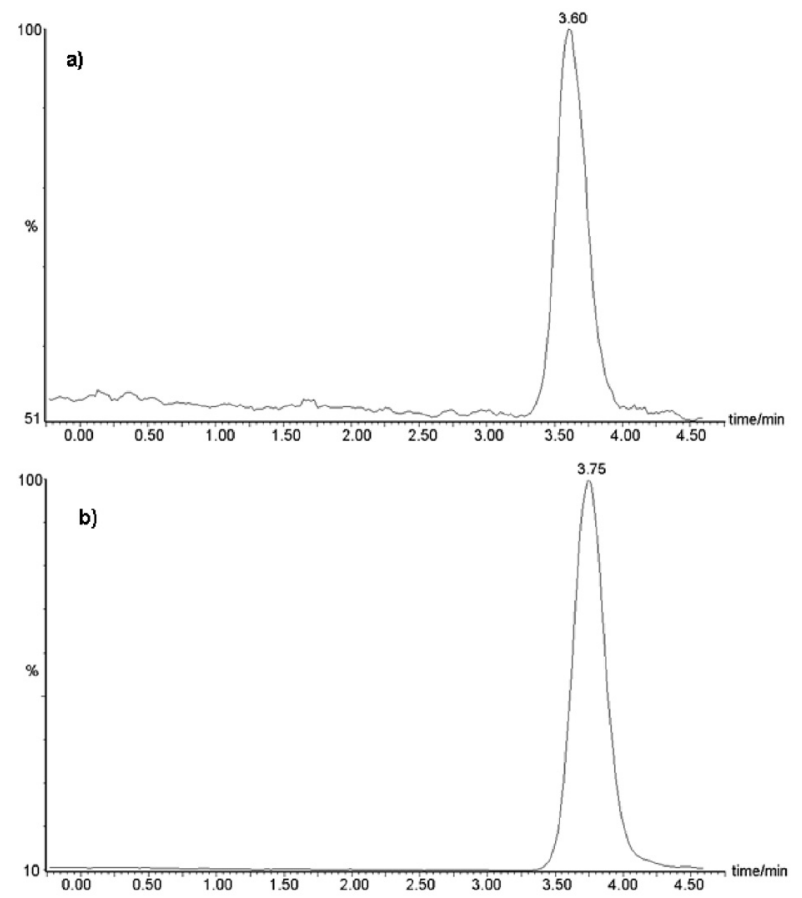

Figure 3. MRM chromatograms of ametryn $\left(0.5 \mathrm{ng} \mathrm{g}^{-1}\right)$ (a) and surrogate $\left(10 \mathrm{ng} \mathrm{g}^{-1}\right)$ (b) of a spiked sediment sample. Selected ions $\mathrm{m} / \mathrm{z} 228>186$ (ametryn) and 285 > 154 (surrogate). Mobile phase, methanol: ammonium

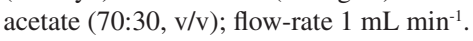

results showed RSD values lower than $13 \%$ and error values lower than $2 \%$ for all samples analyzed (Table 4$)$. The quantitation limit of the method was $0.1 \mathrm{ng} \mathrm{g}^{-1}$, evaluated in quintuplicates $(\mathrm{RSD}=7.0 \%$ and accuracy $=0.4 \%$ ). All values of RSD and accuracy obtained for the parameters analyzed in the method validation were considered acceptable according to literature. ${ }^{28,29}$ The detection limit calculated at signal noise ratio $=3$ was $0.029 \mathrm{ng} \mathrm{g}^{-1}$. Literature data shows detection limit for triazine analysis in soil by LC-MS or LC-MS-MS of $0.5 \mathrm{ng} \mathrm{g}^{-1} 17$ and quantitation limits from 0.15 to $0.3 \mathrm{ng} \mathrm{g}^{-122}$ and $1.5 \mathrm{ng} \mathrm{g}^{-1} .^{17}$ So, the limit of quantitation obtained in this study is among the lowest values for triazine analysis in soil or sediment. Thereby, the method developed may be suitably employed for the analysis of river sediment, which is an important matrix to be evaluated in environmental analysis, once pesticides in sediment can contaminate organisms present in the aquatic ecosystem.

\section{Method for bivalve analysis}

To eliminate matrix interference as much as possible, the extraction procedure was developed in two steps, one acid, where the ametryn is protonated and solubilized in the aqueous phase, and another basic, involving the extraction of non-protonated ametryn by the organic solvent. $\mathrm{NaCl}$ was added to the aqueous phase to improve the transference of the analyte to the organic phase (salting out effect).

Figure 4 shows the MRM chromatogram of control sample of bivalve Corbicula fluminea and a control sample spiked with ametryn and diazepam (surrogate).
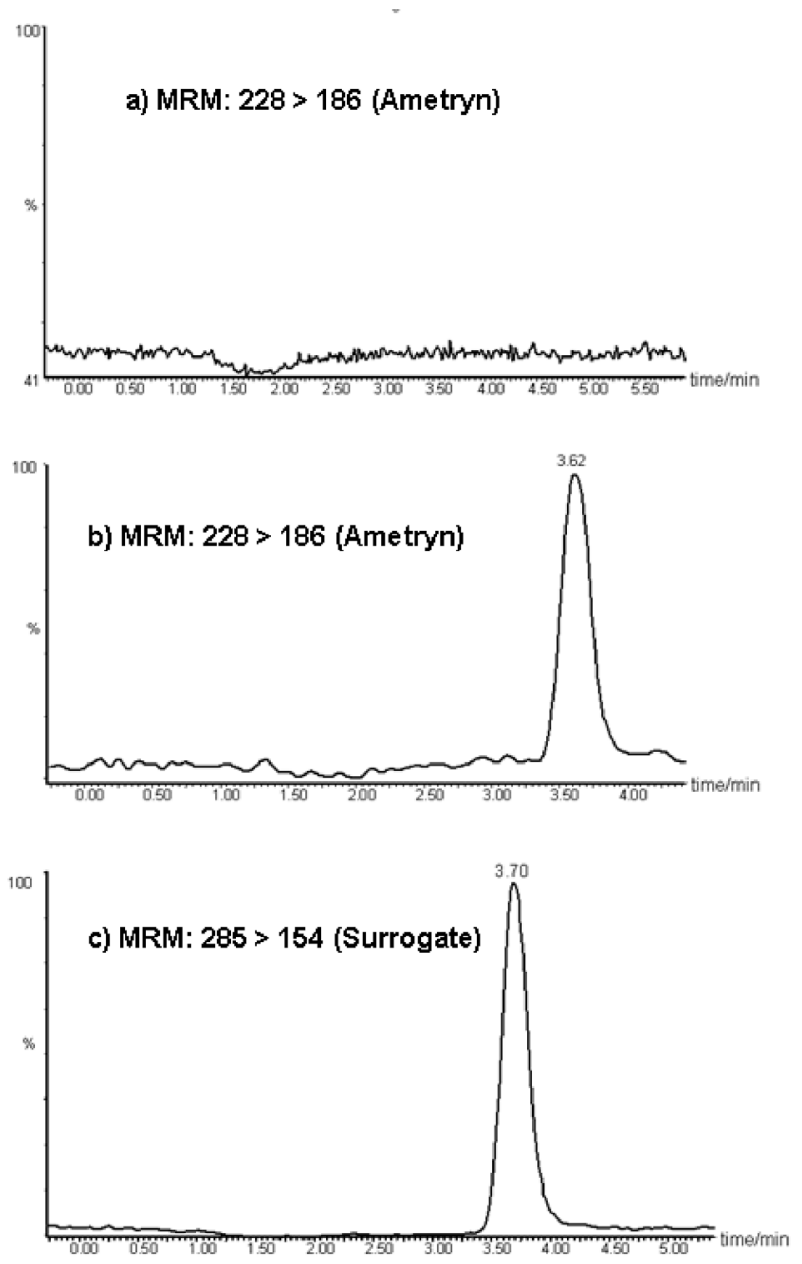

Figure 4. (a) Ametryn MRM chromatograms of a control bivalve sample Corbicula fluminea. (b) and (c) MRM chromatograms of a control bivalve sample of the same specie spiked with ametryn and diazepam (surrogate), in the concentration of $7.5 \mathrm{ng} \mathrm{g}^{-1}$ and $50 \mathrm{ng} \mathrm{g}^{-1}$, respectively. Mobile phase, methanol: ammonium acetate $(70: 30, \mathrm{v} / \mathrm{v})$; flow-rate $1 \mathrm{~mL} \mathrm{~min}^{-1}$.

The results obtained in the method validation are summarized in Table 3 and 4 . The employed extraction procedure resulted mean recovery of $61.1 \%$ and RSD of $13.9 \%$ for ametryn. This relative low recovery is acceptable, due to the sensitive detection performed by mass spectrometry and the reproducible results obtained in the method validation. The limit of quantitation determined was $0.5 \mathrm{ng} \mathrm{g}^{-1}(\mathrm{RSD}=$ $13 \%$ and accuracy $=1.6 \%$ ), in agreement with the literature for validation of liquid chromatographic methods. ${ }^{28,29}$ Some literature data shows limit of quantitation (LOQ) or limit of detection (LOD) values for triazine herbicides by LC-MS or LC-MS-MS in environmental biological samples of $10 \mathrm{ng} \mathrm{g}^{-1}$ 
(LOQ) for food commodities, ${ }^{23}$ from 3 to $80 \mathrm{ng} \mathrm{L}^{-1}$ (LOD) and from 8 to $80 \mathrm{ng} \mathrm{L}^{-1}$ (LOQ) for bovine milk sample, ${ }^{24}$ from 0.012 to $20 \mathrm{ng} \mathrm{g}^{-1}$ (LOD) for food samples, ${ }^{16,25}$ from 0.1 to $14.4 \mathrm{ng} \mathrm{g}^{-1}$ (LOD) and from 0.2 to $31.5 \mathrm{ng} \mathrm{g}^{-1}$ (LOQ) for oyster samples. ${ }^{26}$ In this way, the limit of quantitation for ametryn in bivalve samples, obtained in this study, is among the lowest values for triazine analysis in environmental biological samples.

The pollutants may bioaccumulate in organisms living in water and the bivalves are in the base of aquatic food chain, so the biomagnification is a potential risk. In this way, another advantage of the low limit of quantitation obtained for this method is the ametryn determination before it reaches the superior trophic levels, for example, fish species that can be consumed by humans.

The linearity of the method extended from 0.5 to $25 \mathrm{ng} \mathrm{g}^{-1}$, with $\mathrm{r}=0.997$ (Table 4). The precision and accuracy of the method were performed by replicate analysis $(n=4)$ of bivalve samples spiked with ametryn in
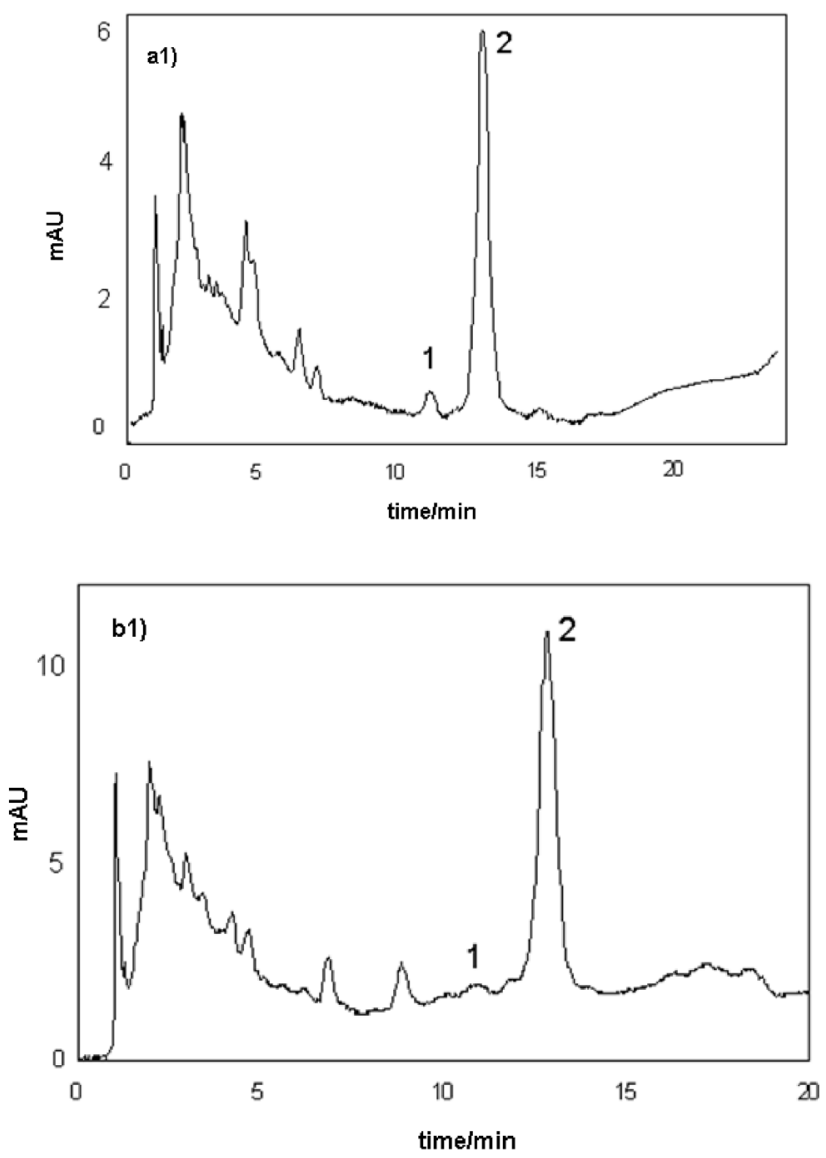

3 concentrations levels. The within-day and the betweenday precision and accuracy values are reported in Table 4. Relative standard deviation and error of less than $15 \%$ were obtained for all samples analyzed.

\section{Environmental samples analysis}

The results obtained by HPLC-UV in the water analysis from the Mogi-Guaçu River and Pardo River indicated the possible presence of the ametryn herbicide, since it was observed a peak in the same retention time of ametryn (Figure 5). To confirm the presence of the ametryn residue, a calibration curve and the water samples from Mogi-Guaçu and Pardo Rivers were analyzed by LC-MS-MS (RP-18 column and mobile phase methanol: ammonium acetate $0.01 \mathrm{~mol} \mathrm{~L}^{-1}, \mathrm{pH} 6.6,70: 30 \mathrm{v} / \mathrm{v}$ ) in the same chromatographic conditions used for the sediment analysis. The results of the water analysis, confirmed by MS, indicated the ametryn presence only in the water sample from Mogi-Guaçu River in
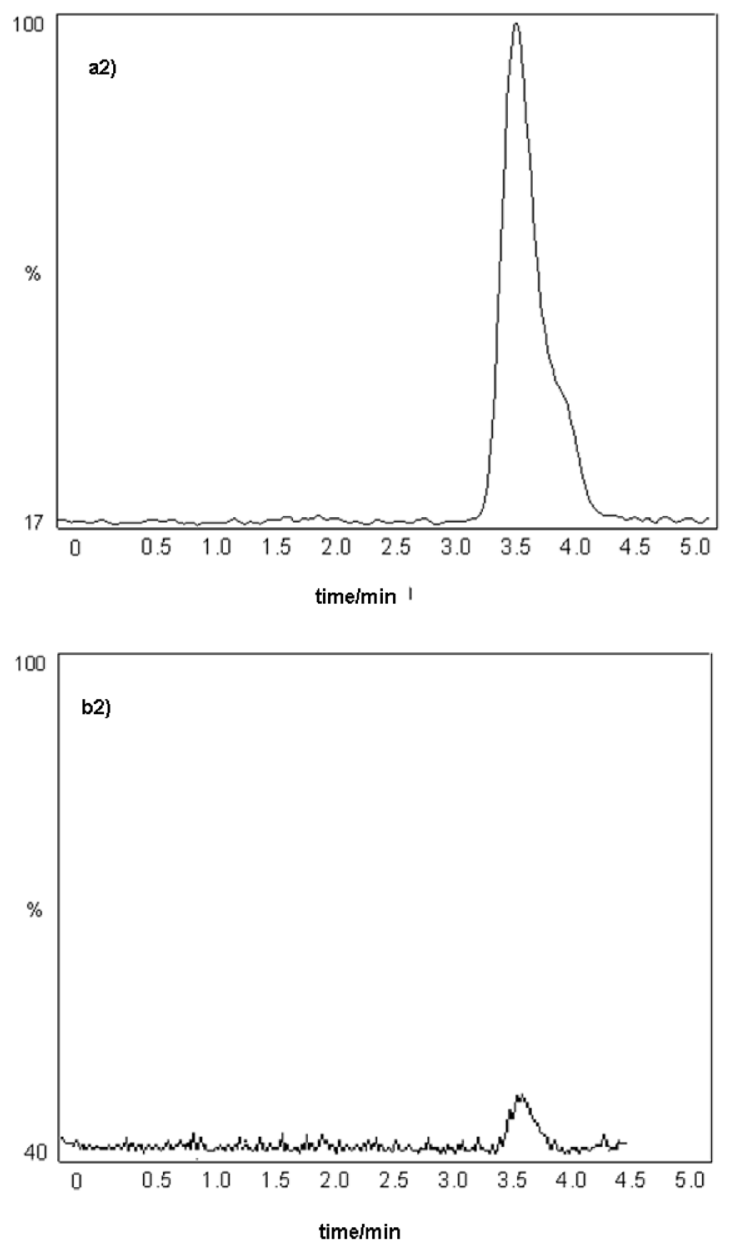

Figure 5. HPLC-UV chromatograms of water sample from Mogi-Guaçu (a1) and Pardo (b1) Rivers and ametryn MRM chromatograms of water sample from Mogi-Guaçu (a2) and Pardo Rivers (b2). Mobile phase in HPLC-UV: methanol:ammonium acetate (55:45, v/v); flow-rate $1 \mathrm{~mL} \mathrm{~min}^{-1}$; UV detection at $230 \mathrm{~nm}$. Peaks: $1=$ ametryn; $2=$ surrogate $\left(500 \mathrm{ng} \mathrm{L}^{-1}\right)$. Mobile phase in LC-MS-MS: methanol: ammonium acetate $(70: 30, \mathrm{v} / \mathrm{v}) ;$ flow-rate $1 \mathrm{~mL} \mathrm{~min}^{-1}$. Selected ion $m / z, 228>186$ (ametryn). 
the concentration of $50 \mathrm{ng} \mathrm{L}^{-1}$ (Table 5). In the water sample from Pardo River, the peak observed in the HPLC-UV chromatogram was not due to the ametryn residue. Figure 5 shows the HPLC-UV and MRM chromatograms of the water samples from Mogi-Guaçu and Pardo Rivers. These results show the importance of the LC-MS-MS analysis to confirm pesticide residues in environmental analysis.

Table 5. Ametryn concentration in river water, sediment and in bivalve samples

\begin{tabular}{lccc}
\hline & \multicolumn{3}{c}{ Ametryn concentration $^{\mathrm{a}}$} \\
\cline { 2 - 4 } & $\begin{array}{c}\text { Water / } \\
\left(\mathrm{ng} \mathrm{L}^{-1}\right)\end{array}$ & $\begin{array}{c}\text { Sediment / } \\
\left(\mathrm{ng} \mathrm{g}^{-1}\right)\end{array}$ & $\begin{array}{c}\text { Bivalve / } \\
\left(\mathrm{ng} \mathrm{g}^{-1}\right)\end{array}$ \\
\hline Pardo River & nd & $0.56 \pm 0.08$ & nd \\
Mogi-Guaçu River & $50 \pm 0.004$ & $0.13 \pm 0.02$ & $1.44 \pm 0.28$ \\
\hline
\end{tabular}

atriplicate for each sample; Mean \pm standard deviation; nd $=$ not detected.

The LC-MS-MS analysis of sediment samples from Mogi-Guaçu and Pardo Rivers showed ametryn presence in both rivers in 2004 in concentrations of $0.13 \mathrm{ng} \mathrm{g}^{-1}$ and $0.56 \mathrm{ng} \mathrm{g}^{-1}$, respectively (Table 5). The major concentration of ametryn in Pardo River sediment is probably due to its higher percentage of organic matter $(9.18 \%)$ compared to other river sediments. These data are in accordance with literature, since it has been reported that triazine residues are associated to sediments with high organic matter, due to its hydrophobic interactions and $\mathrm{H}$-bonds. ${ }^{30-32}$

The results obtained in the analysis by LC-MS-MS of bivalve Corbicula fluminea samples collected from MogiGuaçu and Pardo Rivers indicated the presence of ametryn residue only in the Mogi-Guaçu. This River is localized in northeastern region of São Paulo state, where sugar cane culture is widespread. The ametryn concentration obtained for the bivalve samples in the Mogi-Guaçu River, analyzed in triplicates, was $1.44 \pm 0.28 \mathrm{ng} \mathrm{g}^{-1}$ in the Pradópolis region (Table 5). Figure 6 shows MRM chromatogram of

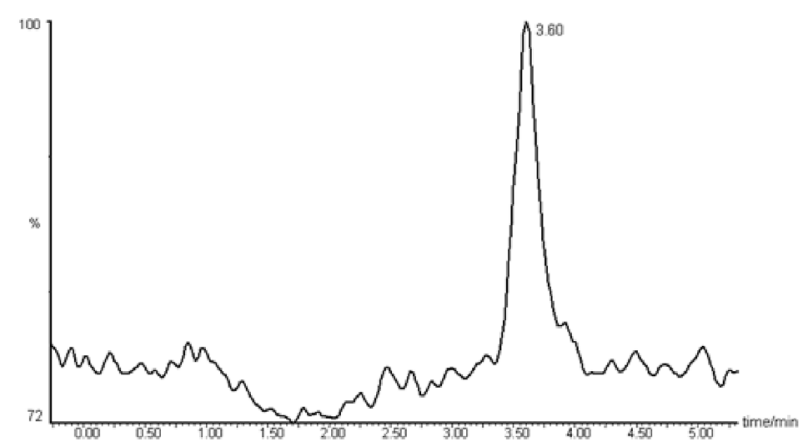

Figure 6. MRM chromatogram of ametryn in the bivalve sample of Corbicula fluminea, from Mogi-Guaçu River, Pradópolis region. Mobile phase, methanol: ammonium acetate $(70: 30, \mathrm{v} / \mathrm{v})$; flow-rate $1 \mathrm{~mL} \mathrm{~min}^{-1}$.
Corbicula fluminea bivalve samples from Mogi-Guaçu River contaminated with ametryn. The concentrations obtained were above the LOQ obtained in the method presented. It indicates that the ametryn has been used in sugar cane cultures and it can reach the aquatic system contaminating the biota.

\section{Conclusions}

The studies carried out for method validation using spiked samples of water, sediment and bivalve mussels indicated that the present methods provide good recovery, precision and accuracy for the analysis of ametryn residues in these matrices. In addition the LC-MS-MS system provided excellent selectivity and sensitivity for the quantitative analysis of ametryn in these environmental samples, allowing the determination of this herbicide in the nanogram levels. These methods were used for the quantification of ametryn traces in water, sediment and bivalve samples collected in Rivers of northeastern region of São Paulo state, Brazil. The analyses of Mogi-Guaçu and Pardo Rivers samples showed the contamination of the aquatic ecosystem by ametryn due to the intensive use of this herbicide through agricultural practices.

\section{Acknowledgments}

The authors acknowledge FAPESP, CAPES and CNPq for financial support and Programa de Pós Graduação em Biologia Comparada (FFCLRP-USP). The authors also wish to thank Alvaro da Silva Costa and Roberto de Carvalho for their assistance.

\section{References}

1. Briggs, S. A.; Basic Guide to Pesticides: Their Characteristics and Hazards, Hemisphere Publishing: Washington, DC, 1992.

2. http://www.iea.sp.gov.br, accessed in December 2007.

3. Gomes, M. A. F.; Memória Seminário Aquífero Guarani, DAEE/ IG (org.), Ribeirão Preto, Brazil, 2003.

4. Armas, E. D.; Monteiro, R. T. R.; Quim. Nova 2005, 28, 975.

5. http://www.pesticideinfo.org, accessed in January 2008.

6. Cerdeira, A. L.; Santos, N. A. G.; Pessoa, M. C. P. Y.; Gomes, M. A.; Lanchote, V. L.; J. Environ. Sci. Health, Part B 2005, 40, 159.

7. Laabs, V.; Amelung, W.; Pinto, A. A.; Wantzen, M.; Silva, C. J.; Zech, W.; J. Environ. Qual. 2002, 31, 1636.

8. Dores, E. F. G. C.; Navickiene, S.; Cunha, M. L. F.; Carbo, L.; Ribeiro, M. L.; Freire, E. M. L.; J. Braz. Chem. Soc. 2006, 17, 866. 
9. Zuin, V. G.; Schellin, M.; Montero, L.; Yariwake, J. H.; Augusto, F.; Popp, P.; J. Chromatogr., A 2006, 1114, 180.

10. Kentucky Division of Water (KDOW); Natural Resources and Environmental Protection Cabinet, Frankfort, KY, 2002.

11. Lopes, J. L. C.; Casanova, I. C.; Figueiredo, M. C. G.; Nather, F. C.; Avelar, W. E. P.; Arch. Environ. Contam. Toxicol. 1992, 23, 351 .

12. Avelar, W. E. P.; Nather, F. C.; Figueiredo, M. C. G.; Casanova, I. C.; Lopes, J. L. C.; An. Acad. Bras. Ci. 1991, 63, 337.

13. Avelar, W. E. P.; Souza, A. D. G.; Lopes, J. L. C.; Casanova, I. C.; Ci. Cult. 1998, 50, 452.

14. Jacomini, A. E.; Avelar, W. E. P.; Martinez, A. S.; Bonato, P. S.; Arch. Environ. Contam. Toxicol. 2006, 51, 387.

15. Vekey, K.; J. Chromatogr., A 2001, 921, 227.

16. Ferrer, I; Thurman, E. M.; J. Chromatogr., A 2007, 1175, 24.

17. Vega, A. B.; Frenich, A. G.; Vidal, J. L. M.; Anal. Chim. Acta 2005, 538, 117.

18. Nogueira, J. M. F.; Sandra, T.; Sandra, P.; Anal. Chim. Acta 2004, 505, 209.

19. Curini, R.; Gentile, A.; Marchese, S.; Marino, A.; Perret, D.; J. Chromatogr., A 2000, 874,187.

20. Di Corcia, A.; Nazzari, M.; Rao, R.; J. Chromatogr., A 2000, $878,87$.

21. Jeannot, R.; Sabik, H.; Sauvard, E.; Genin, E.; J. Chromatogr., A 2000, 879, 51.

22. Dagnac, T.; Bristeau, S.; Jeannot, R.; Mouvet, C.; Baran, N.; J. Chromatogr., A 2005, 1067, 225.
23. Hernández, F.; Pozo, O. J.; Sancho, J. V.; Bijlsma, L.; Barreda, M.; Pitarch, E.; J. Chromatogr., A 2006, 1109, 242.

24. Bogialli, S.; Curini, R.; Corcia, A.; Laganà, A.; Stabile, A.; Sturchio, E.; J. Chromatogr., A 2006, 1102, 1.

25. Okihashi, M.; Akutsu, K.; Obana, H.; Hori, S.; Analyst 2000, 125, 1966.

26. Bichon, E.; Dupuis, M.; Bizec, B.; André F.; J. Chromatogr., $B$ 2006, 838, 96.

27. EC Drinking Water Guideline. 98/83/CE, European Union, Brussels, November 1998.

28. International Conference on Harmonisation (ICH); Validation of Analytical Procedures: Methodology, Q2B (CPMP/ ICH/281/95), 1996.

29. Bressolle, F.; Petit, M. B.; Audran, M.; J. Chromatogr., B 1996, $686,3$.

30. Salomons, W.; Stigliani, W. M.; Biogeodynamics of Pollutans in Soil and Sediments: Risk Assessment of Delayed and NonLinear Responses; Springer-Verlag: Berlin, 1995.

31. Chefetz, B.; Bilkis, Y. I.; Polubesova, T.; Water Res. 2004, 38, 4383.

32. Laabs, V.; Amelung, W.; Pinto, A. A.; Zech, W.; J. Environ. Qual. 2002, 31, 1636.

Received: January 18, 2008

Web Release Date: November 18, 2008

FAPESP helped in meeting the publication costs of this article. 